\title{
CIDADE HISTÓRICA, CIDADE UNIVERSITÁRIA: USOS DO PATRIMÔNIO CULTURAL E REPÚBLICAS ESTUDANTIS EM OURO PRETO, MG.
}

\author{
HISTORIC TOWN, UNIVERSITY CITY: USES OF CULTURAL HERITAGE \\ AND STUDENT RESIDENCE OF OURO PRETO, MG.
}

VILLE HISTORIQUE, VILLE UNIVERSITAIRE: UTILISATIONS DU PATRIMOINE CULTUREL ET DES RÉPUBLIQUES ÉTUDIANTES À OURO PRETO, MG.

CIUDAD HISTÓRICA, CIUDAD UNIVERSITARIA: USOS DEL PATRIMONIO CULTURAL Y REPÚBLICAS ESTUDIANTILES EN OURO PRETO, MG.

Eder Cláudio Malta Souza*

RESUMO: A histórica cidade de Ouro Preto é conhecida pelo significativo patrimônio cultural que representa manifestações da identidade nacional. Desde a fundação da Escola de Minas, em 1876, parte de seu patrimônio foi transformado em repúblicas estudantis que conformam os espaços de sociabilidade pública através de práticas rituais, festivas e formais dos estudantes. $\mathrm{O}$ objetivo deste estudo foi analisar a relação entre o patrimônio histórico, sua preservação e inovação dos usos através das práticas estudantis nos espaços das repúblicas. A pesquisa foi realizada a partir da observação direta a fim de compreender o cotidiano tanto no interior das repúblicas, quanto nas ruas e nos espaços de sociabilidade estudantis. Além de pesquisa bibliográfica e histórica, foram feitos registros fotográficos, entrevistas e conversas informais durante o campo. Propõe-se debater como os usos dos espaços da "Cidade Histórica", apropriados para as ações de preservação do patrimônio histórico para o desenvolvimento da economia turística, são reapropriados por práticas socioculturais que demarcam os lugares da "Cidade Universitária". O que se conclui é que a inscrição socioespacial destas práticas e a paisagem conformada pelas repúblicas imprimem à vida urbana cotidiana de Ouro Preto um espaço público dissonante conflitivo e plural.

\footnotetext{
* Doutor em Sociologia; Professor na Faculdade Maurício de Nassau, Aracaju, SE, Brasil: E-mail: ecmsouza@gmail.com
} 
Palavras-Chave: Cultura urbana; Práticas sociais; Patrimônio cultural; Repúblicas estudantis; Espaço público.

ABSTRACT: The Historical Town of Ouro Preto it known for its significant cultural heritage that represents manifestations of national identity. Since the founding of the School of Mines in 1876, heritage was transformed into student republics that conforms the public sociability spaces through ritual practices, festive and formal of students. This article aims to analyze the relationship between historical heritage, its preservation and innovation of uses through student practices in the spaces of the republics. The research was carried out from the direct observation in order to understand the daily life inside the republics, as well as in the streets and spaces of student sociability. In addition to bibliographical and historical research, photographic records, interviews and informal conversations were performed during the field. It proposed discuss how the use of spaces of the "Historic Town", appropriate for the heritage preservation actions for the development of tourist economy, are reappropriated for the sociocultural practices that demarcate the places of the "University City". What if concludes is that the socio-spatial inscription of these practices print to the everyday urban life of Ouro Preto a dissonant, conflictive and plural public space.

Keywords: Urban Culture; Social practices; Cultural heritage; Student fraternities; Public space.

RÉSUMÉ: La ville historique d'Ouro Preto est connue pour son important patrimoine culturel qui représente des manifestations de l'identité nationale. Depuis la fondation de l'École des Mines en 1876, une partie de son patrimoine a été transformée en républiques étudiantes qui conforment les lieux de sociabilité publique à travers des pratiques rituelles, festives et formelles des étudiants. L'objectif de cette étude était d'analyser la relation entre le patrimoine historique, sa préservation et l'innovation des utilisations à travers les pratiques des étudiants dans les espaces des républiques. La recherche a été réalisée à partir de l'observation directe afin de comprendrer la vie quotidienne à l'intérieur des républiques, ainsi que dans les rues et les espaces de la sociabilité des étudiants. Outre des recherches bibliographiques et historiques, des archives photographiques, des entretiens et des conversations informelles ont été effectués sur le terrain. Il est proposé de discuter de la manière dont les utilisations des espaces de la "ville historique", appropriées pour les actions de préservation du patrimoine historique pour le développement de l'économie touristique, sont réappropriées par des pratiques socioculturelles qui délimitent les lieux de la "ville universitaire". La conclusion c'est que l'inscription socio-spatiale de ces pratiques et du paysage conformé par les républiques s'ins- 
crit dans la vie urbaine quotidienne d'Ouro Preto, un lieu public dissonant, conflictuel et pluriel.

Mots-clés: Culture urbaine; Pratiques sociales; Patrimoine culturel; Républiques étudiantes; Lieu public.

RESUMEN: La histórica ciudad de Ouro Preto es conocida por el significativo patrimonio cultural que representa manifestaciones de la identidad nacional. Desde la fundación de la Escuela de Minas, en 1876, parte de su patrimonio fue transformado en repúblicas estudiantiles que conforman los espacios de sociabilidad pública a través de prácticas rituales, festivas y formales de los estudiantes. El objetivo de este estudio fue analizar la relación entre el patrimonio histórico, su preservación e innovación de los usos a través de las prácticas estudiantiles en los espacios de las repúblicas. La investigación fue realizada a partir de la observación directa a fin de comprender lo cotidiano en el interior de las repúblicas, como en las calles y en los espacios de sociabilidad estudiantiles. Además de investigación bibliográfica e histórica, se realizaron registros fotográficos, entrevistas y conversaciones informales durante el campo. Se propone debatir cómo los usos de los espacios de la "Ciudad Histórica", apropiados para las acciones de preservación del patrimonio histórico para el desarrollo de la economía turística, son reapropiados por prácticas socioculturales que demarcan los lugares de la "Ciudad Universitaria". Lo que se concluye es que la inscripción socioespacial de estas prácticas y el paisaje conformado por las repúblicas imprimen a la vida urbana cotidiana de Ouro Preto un espacio público disonante conflictivo y plural.

Palabras clave: Cultura urbana; Prácticas sociales; Patrimonio cultural; Repúblicas estudiantiles; Espacio público.

\section{INTRODUÇÃO}

A patrimonial cidade de Ouro Preto/MG tem na cultura juvenil universitária uma característica distintiva na vida cotidiana. No entremeio de um conjunto de bens patrimoniais que remetem às construções do barroco mineiro e às manifestações da identidade nacional, as Repúblicas Estudantis também conformam a paisagem cultural do Conjunto Arquitetônico e Urbanístico de Ouro Preto Patrimônio Cultural da Humanidade desde 1980 pela Unesco. Estas também se caracterizam como espaços de manifestação de memórias, tradições, sociabilidades e de práticas urbanas que constituem a vida social da cidade desde o início do século XX. 
Os usos do espaço público, a imagem e a cultura urbana contemporânea de Ouro Preto são, em geral, associados às políticas de preservação do patrimônio histórico e ao desenvolvimento do turismo e dos serviços de consumo cultural. Mas também são, em certa medida, decorrentes das práticas dos estudantes universitários e das instituições que os representam: a Universidade Federal de Ouro Preto e a Escola de Minas (Carvalho, 1978; Dequech, 1984; Cifelli, 2005; Malta, 2012). Com base nos estudos das culturas juvenis para o entendimento da vida cotidiana (Martin-Barbero, 1997; Margulis e Urresti, 2000; Pais, 2003, 2007; Nilan e Feixa, 2006; Stecanela, 2009), entendemos que a presença marcante dos estudantes inscreve formas de sociabilidades e composições visuais diferenciadas que descortinam a reificada identidade histórico-patrimonial ouro-pretana.

O presente artigo tem como ponto de partida discutir sobre a cultura urbana, o turismo e os usos do patrimônio histórico de Ouro Preto. A partir de pesquisa qualitativa, foram realizadas visitas à cidade ao longo de dez anos, em períodos espaçados desde 2008, quanto tivemos o primeiro contato com os estudantes moradores de repúblicas - os republicanos ${ }^{1}$ - e pudemos construir um quadro analítico sobre os estilos de vida e as práticas sociais. Utilizamos recursos como fotografias, entrevistas e conversas informais durante o campo, com realização de observação direta do cotidiano e dos eventos realizados tanto no interior das repúblicas, quanto nas ruas e nos espaços de sociabilidade estudantis.

Nossa análise ocorreu principalmente no Centro Histórico da cidade, tendo realizado observações em diferentes períodos. $\mathrm{O}$ objetivo foi compreender a relação entre o patrimônio histórico, sua preservação e inovação dos usos através das práticas estudantis no cotidiano urbano e nos espaços das repúblicas construídas em antigos sobrados. Observamos os saberes-fazeres não circunscritos ao âmbito acadêmico e à trajetória curricular dos alunos, como sugere Stecanela (2009, p.65), para escrever "sobre as formas como os jovens [...] 'fabricam' sua própria vida, reinventando seus modos de ser

1 Categoria nativa usada pelos moradores de repúblicas. Esta autodenominação serve como forma de distinção entre os turistas e os estudantes que não participam do sistema de repúblicas da Universidade Federal de Ouro Preto (UFOP). 
jovem a partir de sua situação juvenil e aprendendo em suas trajetórias não escolares a partir das suas experiências cotidianas".

Ao apresentar uma definição sociológica de cidades, Wirth (1997, p.46) observou a existência de numerosas tentativas de acadêmicos para "identificar as características distintivas da vida urbana". Este autor declinou das tentativas de definir as cidades e a cultura urbana com base na sua dimensão - algo que ele considerava uma caracterização arbitrária -, pois, segundo ele, sua influência se propaga para além das espacialidades. Wirth observou o urbanismo nas comunidades pequenas que se encontram no raio de influência de uma metrópole em detrimento de cidades maiores interioranas ou de predominância rural. O contraste dos modos de vida nas cidades está entre a cultura urbana e a rural, pois o conceito de urbanismo não é correlato às entidades físicas, mas sim aos modos de vida.

Em torno deste objetivo, dedicamos atenção particular à forte inscrição sociossimbólica que esta cultura imprime ao cotidiano ouro-pretano, ao passo que ressignifica a imagem patrimonial e faz da cidade um espaço identitário dissonante de práticas sociais, conflitivas e plurais. Para Costa (2002, p.16) “o caráter plural e plástico, contextual e interativo, mutável e entrelaçado das identidades culturais, e as profundas ambiguidades de que muitas vezes se revestem nas suas manifestações simbólicas e nas suas dinâmicas relacionais" devem ser pensados e analisados à luz de uma conceitualização não essencialista. Neste sentido, estudamos as práticas sociais - sociabilidades públicas e os modos de habitar (Certeau, 1994; 1995) - dos moradores de repúblicas, que caracterizam a "cidade universitária" e seus diferentes contextos de significações e espacialidades.

\section{CIDADE HISTÓRICA: A IMAGEM PATRIMONIAL DE OURO PRETO}

O Conjunto Arquitetônico e Urbanístico de Ouro Preto, a exemplo das cidades que compõem a lista do Patrimônio Mundial da UNESCO - como os Centros Históricos de Olinda/PE (1982), Salvador/BA (1985), São Luís/MA (1997) e Diamantina/MG (1999) 
—, está entre sítios patrimoniais que representam o período colonial brasileiro. Estes sítios são representados como símbolos da identidade nacional através da prestigiada monumentalidade da arquitetura colonial portuguesa, além de serem considerados patrimônios que reportam à cultura europeia e africana no Brasil (Unesco, 2010).

$\mathrm{O}$ acervo de bens culturais coloniais expressa a imagem patrimonialista (Fortuna, 1997) de Ouro Preto ao acentuar a dimensão simbólica do patrimônio material e imaterial, visto que os costumes, as formas de expressão da vida local e regional, as celebrações, os modos de fazer e viver, os lugares e a arquitetura monumental são privilegiados como marcos identitários da cidade. A área central conforma uma imagem expressiva da arquitetura e da cultura ouro-pretana em diferentes períodos. Remonta também a importantes transformações econômicas, ambientais, administrativas e tecnológicas desde a colonização portuguesa, entre os séculos XVII e XVIII, à modernização da cidade em fins do século XIX em diante.

A cidade de Ouro Preto foi declarada Monumento Nacional em 1933 e tornou-se "a principal relíquia do passado nacional a ser preservada" (Oliveira, 2008, p.114). Com a criação do Instituto do Patrimônio Histórico e Artístico Nacional (IPHAN), em 1937², durante os desdobramentos do Movimento Modernista no Brasil, a noção de patrimônio cultural foi revisada a partir de novos fundamentos que não se restringiam aos aspectos estéticos, mas que abrangiam a historicidade pertinente à construção socioespacial dos centros históricos, seu caráter documental, sua trajetória e seus diversos componentes como expressão cultural do povo brasileiro (Motta, 1987).

Gonçalves (2015) argumenta que a política de patrimônio orientava-se pela construção de uma identidade nacional brasileira dirigida pelo Estado "sob a perene condição de possível perda de sua forma original ou de sua 'autenticidade"' (Gonçalves, 2015, p.216). Intelectuais modernistas, como Rodrigo Melo Franco de Andrade (1898-1969) e Aloisio Magalhães (1927-1982), defendiam a salvaguarda dos marcadores e tradições do passado histórico-cultural brasileiro, e que cabia “às agências de preservação resgatá-lo de um nal - SPHAN, alterado para IPHAN em 1970, através do decreto $n^{\circ} 66.967 / 1970$. 
suposto processo de declínio e desaparecimento" (Gonçalves, 2015, p.216). Estes intelectuais associaram a concepção de patrimônio à construção do futuro da nação. O passado tornou-se, portanto, uma fonte de inspiração para o presente e para o futuro desejável do país. Era a chamada política cultural de "pedra e cal", executada principalmente pelo Estatuto do Tombamento.

Lúcio Costa, arquiteto que idealizou o Plano Piloto para a construção de Brasília, executada mais tarde por Oscar Niemeyer, foi um dos responsáveis por idealizar a cidade de Ouro Preto como obra de arte e promover intervenções com vistas a recuperar o traçado urbano edificado e o acervo cultural. Este vinha em processo de deterioração desde a transferência da capital de Minas Gerais para Belo Horizonte em 1897, quando a cidade colonial perde o título de capital da Província de Minas e parte da população local migra, principalmente os funcionários públicos, militares, comerciantes e famílias tradicionais. $\mathrm{O}$ discurso e as ações empregadas foram no sentido de reverter a estagnação econômica de quase meio século e o quadro de esvaziamento populacional e dos imóveis antigos nesse período das primeiras intervenções, muitos deles já haviam sido ocupados pelos estudantes da Escola de Minas, constituindo as primeiras casas estudantis.

Conforme Motta (1987, p.111), a preocupação maior do IPHAN foi a de "ajustar melhor a arquitetura nova ao quadro antigo, diminuindo o contraste entre o passado e o presente sem reproduzir as velhas construções". Neste caso, fizeram o uso de linhas ou elementos tipológicos da arquitetura tradicional que harmonizassem a paisagem urbana da cidade, a exemplo da marcação dos esteios do pau-a-pique colonial. A autora destaca que, aos poucos, a população solicitava projetos de reforma ou de construção de casas no entorno do Centro Histórico, mas não necessariamente conforme as premissas do IPHAN acerca da identidade nacional. Então foi necessário normatizar as construções e as fachadas de acordo com as exigências caracterizadas pelos critérios estéticos do órgão que definem o "estilo Patrimônio" - empregado também nas novas áreas que se formavam na periferia e morros. 
Neste entretempo, iniciaram-se as construções de projetos arquitetônicos de estilo neocoloniais do início do século XX. O IPHAN teve como referência a nova arquitetura modernista, a exemplo da construção do Grande Hotel de Ouro Preto, projeto modernista de Oscar Niemeyer no início dos anos 1940. Os critérios de conservação do IPHAN tornaram-se complexos, pois valorizaram mais as fachadas de tipo colonial em detrimento dos lotes de tipos intermediários de habitação: as pequenas casas de cores, aparência e planos variados e ecléticos.

Nesta intervenção, a cidade foi preservada com critérios corretivos quanto aos usos espaciais e à produção da sua imagem. Segundo Motta (1987, p.110), "a cidade foi usada como matéria-prima para um laboratório de nacionalidade de inspiração modernista, deixando as populações que lá moravam a esta visão idealizada, não sendo elas sequer motivo de referência", visto que um dos objetivos era enquadrar o "bom gosto" da arquitetura modernista. Essa atuação descaracterizou a paisagem urbana através da falsificação do conjunto devido à persistência no controle das fachadas coloniais, que fez produzir uma arquitetura híbrida. Este tipo de atuação deveu-se à crença dos técnicos do órgão de que Ouro Preto não teria possibilidade de crescer mais.

O tombamento do conjunto é decorrente das políticas de intervenções urbanas que contribuíram fortemente para a construção da imagem patrimonialista articulada à consolidação de uma identidade patrimonial e monumental ${ }^{3}$. Em decorrência da excepcionalidade de seu patrimônio e das ações de preservação dos bens históricos, sua imagem urbana é comumente designada por "Cidade Colonial" no que se refere à descrição dos processos de formação urbana até a consolidação da imagem setecentista; e por "Cidade Imperial”, quando é implantada uma série de equipamentos urbanos, como a Estação Ferroviária, as Escolas de Minas, de Farmácia e de Direito e o Liceu de Arte e Ofícios (Meniconi, 1999).

Para Rubino (2008), é preciso notar que, ao ser considerada uma obra de arte por elaborar uma imagem do Brasil como a imagem do que é patrimônio autêntico, sinônimo de uma brasilidade, Ouro Preto foi considerada um sítio de preservação artística, mas bens culturais híbridos, pois estão articuladas às inovações culturais e estéticas. 
com pouca ou nenhuma importância econômica para o país. No entanto, sua eleição, como a de outras cidades mineiras (Diamantina, São João Del Rey, Serro e Tiradentes), deve-se a dois aspectos que coadunam com a política do Estado Novo: era uniforme do ponto de vista estilístico e decadente no que diz respeito à economia. Devido ao traçado das vias, as edificações e os bens culturais, Gonçalves (1996, p. 122) observa que "Ouro Preto e outras 'cidades históricas' de Minas são usadas como espaços simbólicos que dão concretude e autenticam os celebrados eventos da Inconfidência Mineira".

Apesar dos problemas e críticas relacionadas às políticas de preservação patrimonial em Ouro Preto ao longo dos anos, o IPHAN viabilizou que a antiga Vila Rica fosse a primeira cidade brasileira a receber o título de Patrimônio Cultural da Humanidade pela UNESCO em 1980. Já em 1986, o Centro Histórico foi inscrito no Tombamento dos Livro Histórico e do Livro Arqueológico, Etnográfico e Paisagístico e, em 1989, foi finalmente definida a delimitação do perímetro de tombamento da cidade, que atende ao critério de proteção nacional pelo Decreto-lei no 25/19374.

Desse modo, a partir de 1980, Ouro Preto tornou-se nicho de destaque no turismo nacional em consonância com a noção de que o patrimônio cultural é um poderoso aliado para o desenvolvimento econômico das cidades. Tal noção encerrou a visão acerca do patrimônio como fator impeditivo do progresso urbano, pois o turismo patrimonial publiciza a imagem de "Cidade Histórica" e gera renda para parcela da mão de obra. Reconhecida em nível internacional, nacional e regional, a cidade é objeto das políticas de intervenção do programa Monumenta/BID, a partir de 2003, e se consolida como um importante centro de turismo e consumo cultural no país.

Nos anos que decorreram as intervenções do IPHAN, as representações em torno do turismo têm variado entre "Cidade Monumento", "Cidade Patrimônio" ou "Cidade Histórica", o que confere

4 Ao todo, mais de 1.000 imóveis compõem o conjunto tombado como Patrimônio Nacional, que só exclui os bairros da Saramenha e Bauxita. Apesar de estarem na área preservada, 44 monumentos são tombados separadamente. Na Portaria ${ }^{\circ} 312 / 2010$, o IPHAN concentra hoje suas fiscalizações na chamada gestão do patrimônio cultural dos espaços públicos integrantes da Área de Preservação Especial (APE), da Área de Preservação (AP) e da Área de Preservação Paisagística, Arqueológica, Ambiental (APARQ).

5 O termo "Cidade Monumento" é bastante utilizado na literatura acadêmica acerca dos discursos 
e sedimenta à paisagem histórico-cultural valores de preservação, memória, arte, identidade e tradição (Natal, 2007). Uma ideia de identidade cultural ouro-pretana foi atribuída por estes elementos que a qualificam através da preservação da arquitetura e da discursividade dos contextos históricos, políticos e estéticos tradicionais. No entanto, apesar de sua importância para o cotidiano e também para a economia da cidade, tal atribuição identitária não compreende a cultura urbana estudantil e sua imagem de "Cidade Universitária".

Conforme Costa (2002, p.27), os processos de atribuição identitária de um lugar "reportam-se a construções discursivas ou icônicas de entidades coletivas, com as quais aqueles que as produzem não têm relação subjetiva de pertença”. Estes processos ainda podem constituir a "reificação histórico-patrimonialista" dos centros ou cidades antigas que, em contrapartida, tendem a inverter e desconstruir as narrativas e representações de um lugar. Projetos de preservação patrimonial têm como base relacionar a conservação do patrimônio histórico ou vernacular a um modelo de planejamento urbano de intervenção paisagística e recomposição da imagem da cidade para alterar os sentidos e os usos conferidos ao patrimônio cultural (Leite, 2015). Para Tamaso (2006, p.246),

Ao receber a atribuição de valores que devem garantir o fundamento da identidade coletiva, o bem cultural, transfigurado em bem patrimonial, passa a ser referido com base nos valores propagados pelos discursos oficiais e institucionais - valores históricos e estéticos -, não obstante a preexistência de outros sentidos atribuídos pela experiência cotidiana e subjetiva com aquele (ou naquele) bem cultural - valores afetivos, suportados pela memória do lugar.

Nos discursos oficiais, os patrimônios culturais representam a história, as narrativas, os símbolos nacionais, a identidade da nação discursivamente construída a partir de uma suposta "diversidade cultural" (Gonçalves, 2015) e seu sentimento de pertença comunitário e de integração ao conjunto de bens: relíquias, monumentos, síimagem patrimonial, conforme designada pela UNESCO. 
tios ou centros históricos etc. Em tese, amplia-se o sentido conferido pela sociedade às diferentes formas de apropriação do patrimônio cultural material e imaterial.

Os discursos de instituições como o IPHAN, o Ministério Público Federal, a Prefeitura Municipal de Ouro Preto e associações locais de moradores e de estudantes buscam convergir entre si no sentido de que o patrimônio precisa ser preservado e, por isso, faz-se necessário o controle e a fiscalização dos usos dos equipamentos urbanos da cidade, como ruas, a Praça Tiradentes, o casario edificado (residencial e comercial), as Igrejas e Museus. No entanto, os sentidos atribuídos às formas de preservar divergem em suas diversas apropriações, principalmente pelos estudantes quanto aos usos das casas. Debatemos a seguir sobre os usos e os processos identitários das repúblicas estudantis que conformam a "Cidade Universitária", visto que boa parte delas é instalada em prédios públicos e localizam-se no Centro Histórico.

\section{CIDADE UNIVERSITÁRIA: OURO PRETO, A “CIDADE DAS REPÚBLICAS"}

Além das designações que reportam os discursos em torno do passado colonial, Ouro Preto é também conhecida por possuir o maior acervo de repúblicas estudantis do país. Chamada de "Cidade das Repúblicas", possui uma dinâmica vida universitária que tem ressignificado cotidianamente (e de maneira muitas vezes irreverente) os usos do patrimônio edificado. Delimita-se aqui um olhar sobre um tipo de sociabilidade juvenil que, de certo modo, desafia as noções de público e privado (Sennett, 1989; Fortuna, 2002) ao enunciar o espaço privado e da intimidade por meio da "co-presença" de suas práticas e modos de viver nos espaços públicos. A vida estudantil da cidade histórica existe desde 1839, com a fundação da Escola de Farmácia, mas a cultura universitária (suas práticas, tradições, rituais etc.) enuncia-se somente a partir da criação de sua primeira instituição de nível superior, a Escola de Minas de Ouro Preto (EMOP), durante o período de transição do Segundo Reinado brasileiro para o regime Republicano. A EMOP 
foi fundada em 12 de outubro de $1876^{6}$, por iniciativa de Dom Pedro II, durante viagem para a Europa em busca de conhecimentos técnicos de exploração das riquezas minerais do Brasil, sobretudo na região de Minas Gerais (Carvalho, 1978).

Ouro Preto, desde o fim do século XIX, ficou conhecida como uma das principais cidades universitárias do país, ao lado de Rio de Janeiro, Salvador e Olinda. Foi também a primeira cidade brasileira a registrar um sistema de repúblicas estudantis que surgiu no início do século $\mathrm{XX}$, quando o regime monárquico perdia força política no Brasil (Machado, 2007). Os estudantes ocuparam antigos imóveis da área central abandonados pela população que migrou para a nova capital, Belo Horizonte. Segundo Machado (2003, p.197), "as repúblicas assumiram papéis importantes na conservação e na divulgação do patrimônio histórico". A antiga cidade colonial passou a ser chamada de "Cidade das Repúblicas" e, desde o surgimento, as primeiras moradias tornaram-se espaços de socialização contínua entre os estudantes, ex-estudantes e também professores, no entanto, com forte interação conflitiva com os moradores "nativos"7 ouro-pretanos.

Após a fundação da Universidade Federal de Ouro Preto (UFOP), em 21 de agosto de 1969, foram incorporadas as Escolas de Minas e de Farmácia. Neste entretempo, aumentou o número de alunos e diversificaram-se as repúblicas estudantis. Inicialmente foram instaladas nas antigas casas do Centro Histórico, e são atualmente propriedades da UFOP. Com a criação da Universidade, antigos imóveis no centro histórico foram doados ao patrimônio da EMOP para suprir a falta de moradias para estudantes, e algumas casas onde foram instaladas repúblicas tornaram-se pertencentes à União.

Entre as décadas de 1960 e 1970, período anterior à revalorização dos antigos sítios brasileiros, protestos e manifestações estudantis resultaram na compra sistemática de casas que se tornaram repúblicas e foram tombadas como patrimônio da Universidade, pois os preços dos imóveis no centro histórico eram considerados razoáveis e havia forte demanda por moradia. Nos anos seguintes, houve 
a construção de alojamentos estudantis no Morro do Cruzeiro, onde se localiza atualmente o campus da UFOP.

Desde então, as repúblicas ${ }^{8}$ tornaram-se um tipo de moradia regulada pela UFOP (que oferece também os Alojamentos Estudantis), chamadas de Repúblicas Federais que funcionam tanto com base nas tradições e códigos culturais para os usos e formas de habitar a casa - sistema de "repúblicas tradicionais" constituídas no decorrer do século XX -, quanto subordinadas ao Estatuto das Residências Estudantis que fundamenta as normas administrativas para cada casa a ser administrada pelos próprios moradores. Em sua maioria, são as mais antigas da cidade e habitam o casario edificado no centro histórico ou nas áreas de propriedade da UFOP.

Além das Repúblicas Federais existem as Repúblicas Particulares, criadas em casas alugadas pelos estudantes em imobiliárias ou diretamente com os proprietários de imóveis. Estas são muitas vezes efêmeras, e a grande maioria não faz parte do sistema de "repúblicas tradicionais". São formadas pelos estudantes que não conseguiram ou desistiram das vagas oferecidas nas Federais, mas recebem o apoio jurídico da UFOP, no que diz respeito ao relacionamento com os locatários. A divisão entre repúblicas tradicionais ou não tradicionais condiz somente com a inscrição de cada residência, federal ou particular, às práticas acadêmicas, perpetuadas desde a fundação das primeiras repúblicas na cidade. São também dividias por recorte gênero, entre repúblicas masculinas e femininas, ainda que existam as repúblicas mistas.

As residências estudantis estão espalhadas em diversos bairros, principalmente no Centro Histórico e bairros do entorno (Antonio Dias, Lajes, Pilar e Rosário), que detêm vasto acervo patrimonial de bens culturais materiais que remontam à arquitetura e urbanismo do barroco mineiro e de bens imateriais referentes às narrativas políticas, artísticas e simbólicas da identidade nacional (Motta, 1987; Rubino, 2008). Mas, desde a adesão da UFOP ao Programa de Apoio a Planos de Reestruturação e Expansão das Universidades Federais (REUNI) em 2007, uma das principais localidades em que estão instaladas as novas repúblicas, principalmente particulares, é o bairro 
operário da Bauxita. Localizado no Morro do Cruzeiro, o bairro passa por um processo de reestruturação urbana a partir da migração de sua população nativa para outras áreas vizinhas, que alugam seus imóveis a fim de viver de renda ou obter renda extra com aluguéis e prestação de serviços (lavanderia, limpeza, cozinha etc.).

Este processo de substituição de moradores nativos por estudantes é chamado por Smith (2005) de studentification (estudantificação), neologismo derivado do conceito de gentrification. Segundo Leite (2007, 2015), por gentrification (gentrificação/enobrecimento urbano) entende-se a transformação dos espaços e da paisagem às demandas dos mercados (imobiliário, segurança, planejamento e saneamento urbano) com forte apelo visual para atração das classes médias e altas. Esse modelo de intervenção tem como consequência um alto grau de segregação e fragmentação do espaço em diferentes lugares e de assimetria socioeconômica. Apesar de reconhecer tais características, tomo por empréstimo o termo "estudantificação" sem tornar estrita sua relação com conceito de gentrificação, dado que serviços de varejo e noturnos mais caros são evitados por estudantes de faixa de renda mais baixa.

Smith (2005) observa que tal processo decorre da inflação imobiliária (residencial e comercial) nos bairros universitários ou áreas com grande concentração residencial de estudantes de ensino superior. A mudança de residentes promove impactos socioculturais, econômicos e dos usos físicos e simbólicos de um bairro, principalmente quando se instala ou amplia-se um campus universitário e instituições de ensino superior. A concentração de estudantes em um bairro intensifica a criação de guetos estudantis, tanto em decorrência da apropriação do espaço público por estes, quanto por meio de estratégias intencionais de arrendamento imobiliário feitas pelas instituições do setor público e privado, tais como promotores imobiliários, investidores, governo local, setores varejistas, de lazer, turísticos e da mídia - que são também intermediários culturais.

Para o autor, apesar das oportunidades de renda dos proprietários de imóveis, a relação entre estes conceitos decorre da segregação dos usos e da ampliação da polarização socioespacial e econômica das 
cidades devido ao deslocamento de grupos residenciais estabelecidos. Mesmo que tenha diversas acepções e formas de investimento, é um processo material liderado pelo capital, mas geralmente intermediado por agentes institucionais de pequena escala, que são os "empreendedores orgânicos" (Smith, 2005). São pequenos proprietários de imóveis e investidores locais que constroem ou reformam prédios e até a casa própria para alugar aos estudantes que formam repúblicas ou vivem em sistema de pensionato, reconhecendo-se nas cidades universitárias uma oportunidade de maximização de lucros 9 .

É no Centro Histórico e bairros do entorno que as repúblicas federais são mais visíveis, e estão no entremeio dos diversos empreendimentos turísticos da rede hoteleira, restaurantes e museus, e aderem à paisagem histórica da cidade. As repúblicas são também espaços de visitação para turistas conhecerem antigas casas do centro. O turismo estudantil é um aspecto relevante para as repúblicas, principalmente em períodos festivos como o carnaval e a tradicional Festa do 12 de Outubro que atraem turistas de todo o país e as repúblicas tornam-se espaços de hospedagens para visitantes e ex-moradores. Conforme Cifelli (2005, p.156), “dentre as modalidades de turismo mais atuantes em Ouro Preto destacam-se o turismo cultural, o turismo religioso, o turismo estudantil, envolvendo grupos de estudantes do ensino fundamental, médio e superior, o turismo de eventos, comércio e o excursionismo". Há porões que se transformaram em espaços de exposição de artes ou baladas noturnas, outras são conhecidas pelas dezenas de corredores e quartos, o que corresponde aos usos do passado. Este turismo estudantil flexibiliza o contato entre moradores e visitantes no contexto da Cidade Patrimônio.

As mudanças culturais e econômicas intermediadas pela chamada "atrofia ou crise do espaço público", sujeito à lógica do mercado. Dentre as causas de tal atrofia, Fortuna (2002) entende que a relação do espaço privado intrafamiliar com o espaço público e sua dinâmica exterior ocorre em confluência com a globalização da cultura e das tecnologias. Quanto a isso, os efeitos mais diretos da

9 No Brasil, diversas cidades como Pelotas (RS), Campina Grande (PB) e Campinas (SP) possuem forte relação econômica entre a cidade e as Universidades, mesmo que não possuam a configuração de uma cidade universitária nos moldes de Ouro Preto e Coimbra (Portugal), ainda assim a população investe em imóveis de múltipla ocupação dado o fluxo sazonal de alunos. 
globalização incidem na vida pública, na participação cívica-cidadã, na massificação e estetização dos consumos, no planejamento urbano e na construção das imagens identitárias das cidades em torno de seus espaços que conformam o que chama de "colonização do espaço público urbano" (Fortuna, 2002, p.131).

Ao invés de uma superação do privado sobre o público, da ruptura da individualidade dos sujeitos e suas intimidades domésticas com a sociabilidade pública, a "casa" não está ausente dos agentes, instituições e situações que lhe são exteriores - o que, em certo sentido, pode-se apontar na dinâmica das repúblicas estudantis. A comunicabilidade urbana mediada pelas novas tecnologias de algum modo fez emergir um novo ethos cosmopolita, com efeitos significativos no relacionamento entre os visitantes e os republicanos, principalmente no que tem efeito sobre a ruptura das dicotomias modernas eu/outro e público/privado.

O que ocorre não é a retração do espaço público, mas a implosão do espaço privado e da intimidade que se deve pela "co-presença" dos visitantes - turistas e convidados - destas novas tecnologias de comunicação e mídias digitais no espaço intrafamiliar, que podemos exemplificar com o uso da TV e internet, ou com mídias digitais como o AirBnb. Num sentido geral, o espaço privado está também a ser colonizado pelo cotidiano público da cidade (Fortuna, 2002), sendo este o caso de muitas repúblicas que publicizam suas imagens cotidianas e festivas na internet e redes sociais. Tal perspectiva recusa a ideia de morte/retração do espaço público ou disjunção entre os indivíduos e a cidade preconizada por Sennett (1998), pois a relação da privacidade do lar com o espaço público se dá a partir da porosidade das fronteiras entre estes domínios públicos e privados.

A vida universitária está presente através da inscrição das repúblicas na paisagem urbana em conformidade com os usos do patrimônio e pelo modo como os estudantes se apropriam destes espaços e manifestam estilos de vida distintos. Esta é, pois, a importância da Universidade e suas repúblicas — que fazem da "Cidade Histórico -patrimonial" também uma "Cidade Universitária". 


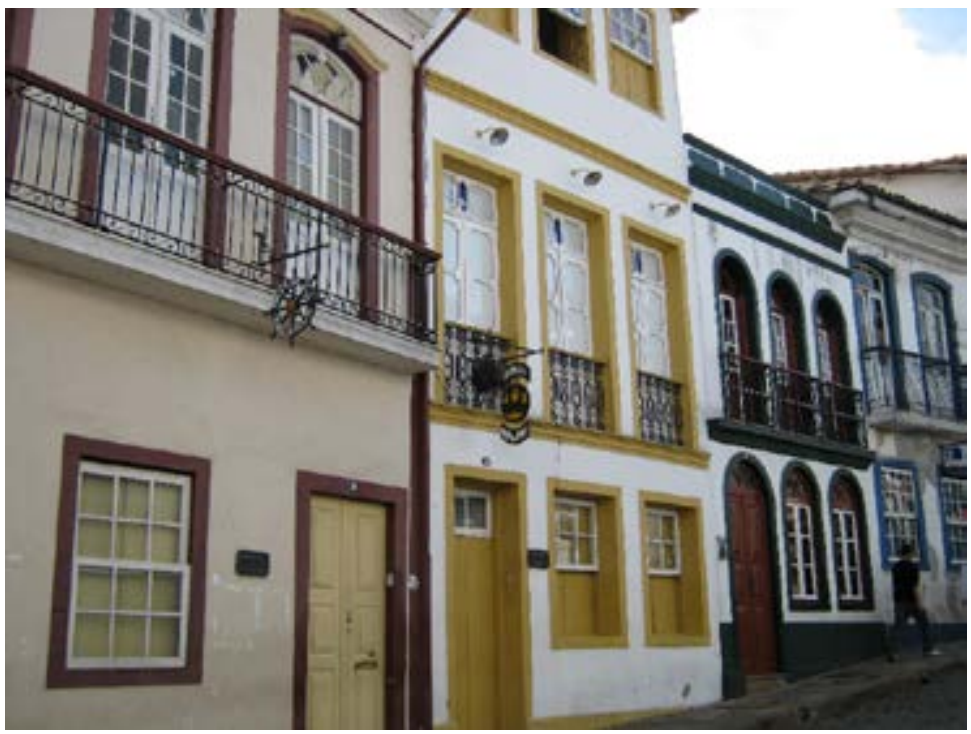

Figura 1 - A paisagem da "Cidade Histórica" e da "Cidade Universitária": Repúblicas Estudantis no Centro Histórico de Ouro Preto. Fonte: Autoral, 2009.

\section{REPÚBLICAS ESTUDANTIS E COTIDIANO}

Em Ouro Preto, havia um "mundão de repúblicas de estudantes” (Lessa, 1981) que chamavam a atenção de visitantes na cidade antes mesmo de sua patrimonialização. Lessa (1981) afirma que as famílias nativas fechavam os olhos às "travessuras" dos universitários. Estas residências foram instaladas em diversos bairros, quando se registrou novas formas de interação com a comunidade "nativa" através de apropriações lúdicas e subversões dos usos dos espaços. Relatadas pela autora como "patuscadas", as travessuras - jogos de sociabilidade - realizadas pelos estudantes tornaram-se referência à medida que provocavam uma inversão do cotidiano na cidade tradicional e religiosa.

David Dequech, ex-aluno do curso de engenharia da Escola de Minas, em seu livro "Isto Dantes em Ouro Preto" (1984), através de 85 contos - os quais em grande parte relatam o cotidiano dos alunos e suas formas de interação com moradores, comerciantes, po- 
líticos e com as autoridades militares e religiosas - demonstra em linhas poéticas como se enunciou a vida estudantil na cidade, em diversas esferas sociais e institucionais. Não só de travessuras viviam os universitários, mas de manifestações próprias do mundo estudantil, fossem elas politizadas ou lúdicas, a exemplo dos trotes feitos com os moradores das repúblicas e com os nativos das cidades, ao enfrentamento político em diversas ocasiões (ditadura militar, reivindicação por moradias etc.), os agregados da EMOP construíram uma cultura urbana de práticas dissonantes.

O sentido proposto por Simmel (2006) sobre a sociabilidade como uma forma autônoma ou lúdica de sociação revela, através do "jogo interativo", a forma pela qual ocorre conjuntamente a interação dos indivíduos ou grupos sociais em razão de seus interesses diversos que podem ser efêmeros ou duradouros, pois é por meio da ação recíproca dos atores sociais que esta interação se constitui no cotidiano. Ao se referir aos usos da rua definida pelo urbanismo, Certeau (1994, p.202) observa que "o espaço é um lugar praticado". Isto é, a rua é transformada em espaço pelos pedestres - os indivíduos que se apropriam dos lugares para a construção dos espaços mediante práticas, usos e narrativas diversas.

Com base nas ideias de Simmel e Certeau, Leite (2007, p.287), concebe a sociabilidade pública, em sentido amplo, "como práticas interativas - conflitivas ou não - que ocorrem na vida cotidiana pública". Tal noção ajuda-nos a pensar sobre o que chamaremos de "jogo da sociabilidade" e nas "fraturas" dos códigos sociais, da memória, do concebido. Como afirma De Certeau (1995, p.244) sobre espaços e práticas:

Lá existe jogo. É o listrado de um bufão: um divertimento, uma transgressão, uma travessia "metafórica", uma passagem de uma ordem a outra, um esquecimento efêmero no interior das grandes ortodoxias da memória. Todos esses movimentos estão relacionados a organizações e a continuidades. Mas aí introduzem a discreta proliferação de criatividade. 
Dentre as diferentes culturas urbanas, a vida universitária constitui espaços públicos de formação das identidades e de sociabilidade. Para Frias (2003), a cultura universitária possui características que conferem às Universidades uma singularidade que deve ser reivindicada para além do fazer acadêmico. Mas, poucos estudos têm como foco o modo como essa cultura redefine a noção de espaço público. Pois, diversas são as formas como

[...] esta configuração complexa de práticas rituais, formais e festivas, acompanhada de uma constelação de imagens, de objectos e de mitos, confere ostensivamente à Universidade os sinais de uma singularidade reivindicada e de uma exemplaridade muito pouco estudada (Frias, 2003, p.81).

A vida estudantil registra, além do fazer acadêmico, recursos de ampla publicização das identidades urbanas e de estilos de vida que constituem diferentes lugares de sociabilidade pública. São práticas sociais e culturais de diversas ordens que articulam universidades e cidades: movimentos estudantis politizados, movimentos de protestos, arte e teatro; música e esporte; intervenções urbanas; práticas culturais e espaços próprios de consumo; eventos universitários etc.

A estudantificação da antiga Vila Rica existe nos interstícios do redescobrimento do barroco mineiro e sua patrimonialização subsequente. A incidência recorrente de uma população juvenilizada e flutuante possibilitou a expansão física e simbólica da universida$\mathrm{de}^{10}$, que foi adequada à Lei do Tombamento do centro histórico, que consistiu na feitura dos códigos de posturas para o uso do solo e dos antigos sobrados onde se instalaram as repúblicas (Queiroz, 1984). Desta forma, nos fins da década de 1960, a UFOP adequou as normas de assistência de alojamento estudantil às leis sociais de usos e de proteção ao patrimônio público.

Convém ressaltar que os aspectos simbólicos e identitários da cultura universitária de Ouro Preto decorrem do intercâmbio de alu-

10 A UFOP possui atualmente 18.174 estudantes em todas as modalidades, que incluem ensino presencial de graduação, pós-graduação e EAD. Dados publicados até setembro de 2018. 
nos brasileiros com a Universidade de Coimbra (UC) desde o século XVIII, quando estudantes brasileiros já faziam intercâmbio na Europa, e Minas Gerais liderou a lista de alunos admitidos na UC e nas universidades de Paris, sendo os principais destinos dos estudantes oriundos de famílias abastadas ou até mesmo filhos de famílias com menos condições. Desse modo, a origem da cultura universitária de Ouro Preto está diretamente relacionada ao intercâmbio estudantil com a cidade de Coimbra, conhecida em Portugal por "Cidade dos Estudantes" (Gomes, 2008), desde a fundação da Escola de Minas.

As duas cidades possuem semelhanças e dessemelhanças acerca das práticas mais tradicionais ou vanguardistas, da organização das repúblicas estudantis e dos usos dos espaços e dos monumentos históricos como lócus de moradia, lazer, vida política e intervenções artístico-culturais. Mesmo que não se verifique atualmente alguma relação direta entre as duas cidades, esta forma de identificação cultural advém do tempo de existência de suas instituições de nível superior - Universidade de Coimbra e Escola de Minas - e da forte inscrição sociossimbólica das repúblicas estudantis em seus espaços (Crivellari, 1998). A UC ainda conta com sua imagem de Universidade de tradições seculares associada à patrimonialização, em 2013, como bem material e imaterial da cidade de Coimbra (Unesco, 2013).

No entanto, que práticas são estas e como se enunciam entre os jovens universitários de Ouro Preto? E por que nos importam estas práticas para estudar a sociabilidade cotidiana desta cultura juvenil em torno do espaço da casa? Tal como De Certeau (1995, p. 141) postula, "para que haja verdadeiramente cultura, não basta ser autor de práticas sociais; é preciso que essas práticas sociais tenham significado para aquele que as realiza". No que se refere ao cotidiano urbano, as práticas consistem na formação de socioespacialidades e inscrevem de modo multipolarizado os usos das cidades. São maneiras de fazer advindas dos diferentes estilos de vida, da criatividade e de práticas espaciais, que também podem significar ações ou movimentos que se manifestam contraditoriamente à paisagem constituída (Certeau, 1994).

No que se refere ao cotidiano das Repúblicas Estudantis, as práticas advêm das repúblicas da cidade de Coimbra, chamadas de 
Praxe Académica, processo sócio-histórico do uso da palavra "Praxe" por volta de 1860 e se traduzem como um "deslocamento de sentido" dos elementos materiais e simbólicos da prática institucional e administrativa das universidades portuguesas (que inclui quadro burocrático, corpo docente e conforma a autogestão dos cursos e as hierarquias de cada departamento). A praxe é uma lógica social retirada da Universidade e se constitui como um registro cultural dos estudantes que se configurou não somente em responsabilidades, mas em sociabilidades lúdicas associadas principalmente à tradição e aos costumes no modo de organização da vida em uma república e sua relação com a cidade: autonomia e autogestão administrativa, divisão de hierarquias entre os moradores, rituais de admissão dos calouros, associativismo e os diversos lances cotidianos e festivos (Frias, 2003).

Neste caso, já bastante ressignificada, a influência da chamada Praxe Académica coimbrã pode ser considerada uma forma de designar as tradições estudantis em Ouro Preto que, por sua vez, além dos elementos sociossimbólicos da universidade como o modelo de autonomia, autogestão e o associativismo, apropria-se de alguns dos rituais, signos, elementos sonoros, linguagens, adereços etc., para uma vida cotidiana e cultural própria chamada de "sistema das repúblicas". Tal sistema não é compartilhado por todos os estudantes, mas é reconhecido pelas repúblicas que seguem a praxe acadêmica. Ele compreende tanto o espaço das casas como a sociabilidade pública cotidiana, principalmente as regras de convívio e suas ritualidades como o julgamento do calouro após um período de "batalha" (de 3 a 6 meses), que, segundo os estudantes, seria uma adaptação lúdica do estágio probatório de um docente recém empossado.

A batalha gera muitos conflitos. Conforme os relatos, a "batalha" é apenas um momento de adaptação e de socialização. O ritual da batalha de vagas não constitui uma disputa entre os calouros, pois as repúblicas oferecem somente a quantidade de vagas que dispõem. Não podem 3 calouros batalhar por 2 vagas na república. Como também não há exploração, há tarefas específicas e as cobranças são feitas para que os calouros não se abstenham dos afazeres e do zelo pela casa: 
Há diversos mitos sobre as repúblicas que generalizam a visão negativa sobre suas tradições. A batalha... Eu nunca falo esse nome porque soa estranho. Você não tá numa batalha, numa guerra. Na verdade, não é isso. É um período de adaptação do calouro. Porque você já tem o calouro que já mora aqui e ele vai tentar passar pra eles como é a convivência em grupo, como é a organização da república. Então se o calouro se adequar a isso e gostar ele vai batalhar pra ficar. Na verdade, não é batalhar para ficar. Ele se esforçar, demonstrar interesse, mostrar convivência, mostrar o método de socialização dele principalmente, né. Que ele tá disposto de morar na república, que gostou de conviver ${ }^{11}$.

Como é retratado neste depoimento, a socialização torna-se o método de inserção do novato na casa. Entretanto, é preciso que ele esteja disposto a se inserir também, publicizando sua identidade. $\mathrm{O}$ estilo de vida de cada um é avaliado pelos demais moradores, observado cotidianamente, não como uma forma de controle, mas para que no dia da escolha estes possam fazer um julgamento contundente. Por isso, o quarto coletivo torna-se importante na configuração fragmentária da casa. Este é o lugar do calouro em que sua identidade de gênero, sua sexualidade, seus hábitos e modo de vida são reforçados ou conflituados à medida que se reconhecem na sociabilidade cotidiana. Já para GTA, ex-morador de república ainda durante o período de graduação, "muitas repúblicas novas não compreendem o sistema das repúblicas tradicionais e a distinção hierárquica, aproveitando-se deste período de vulnerabilidade do calouro para mandar, dizer o que fazer"12. Mas, para Maldada:

Você não tem como aceitar um calouro, por exemplo, que não gosta de morar com muita gente, que quer ter tudo dele individual, separado como se fosse assim... uma pensão memo. Você chega numa casa, vai pro seu quarto, você tem suas coisas ali, fulano tem as coisas dele, então a gente não tem isso. Tem uma geladeira que é da república então a gente faz as compras tudo em conjunto e to-

11 Depoimento concedido por Thiago César da Silva (Maldada), em 29/04/2010. Atualmente é ex-morador da República Nau Sem Rumo.

12 Depoimento concedido por Gustavo Tenório, estudante não republicano, em 29/04/2010. 
dos os gastos são divididos pra todo mundo. Então não tem como você ter sempre só suas coisas. O calouro passa por esse período de adaptação pra ver se ele se adapta ao sistema. Se não se adaptar não tem como a gente escolher morar com uma pessoa que não tem a mínima característica de morar em conjunto ${ }^{13}$.

Conforme argumenta Pais (2007), a vida prática e as ritualidades das pessoas se baseiam na manutenção de certas rotinas e regras de interação na vida cotidiana, mas também na improvisação de lances ou regras próprias que flexibilizam as regularidades da vida social através dos fluxos, temporalidades e espacialidades que a perturbam. Neste sentido, uma das relações entre as repúblicas e a cidade condiz com os usos da rua principalmente no aspecto imagético como o uso de "placas de identificação" pelos calouros e enuncia na paisagem urbana cotidiana uma das formas dos trotes universitários. É quando as tradições das casas "invadem" as ruas.

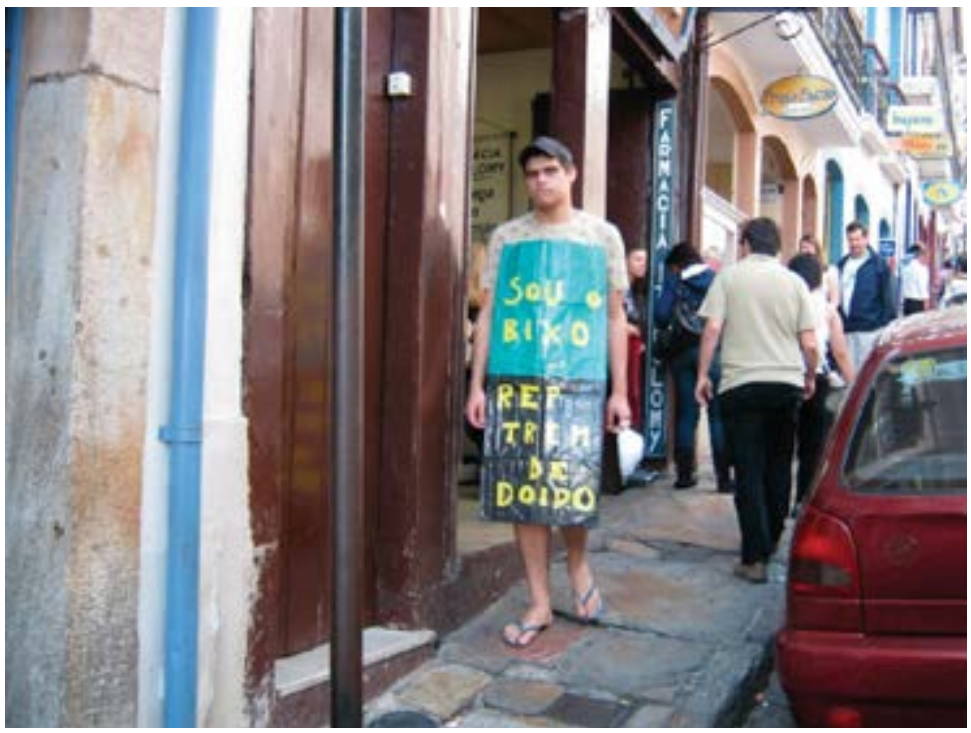

Figura 2 - Trotes com uso de placas: Ritualidades cotidianas dos republicanos universitários. Fonte: Autoral, 2009.

13 Depoimento concedido por Thiago César da Silva (Maldada), em 29/04/2010. Atualmente é ex-morador da República Nau Sem Rumo. 
Com as placas de identificação, o calouro torna-se de algum modo parte do turismo estudantil, visto sua forte visibilidade nas ruas da cidade. Também possibilita que aquela pessoa não se torne um estranho no lugar - não sendo nem turista, nem "nativo", uma vez que as placas reforçam a identidade dos novatos. Além dos trotes, ritos festivos e demais práticas, há o forte vínculo entre as repúblicas, o que amplia as ritualidades entre as chamadas repúblicas irmãs.

Quanto aos usos das casas no centro histórico, há normas estabelecidas entre as repúblicas estudantis, a UFOP e o IPHAN, isto é, a moradia é amparada por estatuto legal (Iphan, 2010). As repúblicas estudantis são então constituídas pela autonomia e autogestão, mas os usos e a preservação do patrimônio edificado estão enquadrados na resolução do Conselho Universitário (CUNI no 1150/2010) da UFOP, pela qual os moradores são responsáveis por qualquer dano ao patrimônio. No Artigo $2^{\circ}$ disposto no Capítulo I deste Estatuto, dispõem-se algumas atribuições necessárias ao bom funcionamento da república e convívio dos moradores.

A ideia geral é oferecer ao estudante morador um ambiente de sociabilidade e estudos com boas condições de moradia. Há também a atribuição para que a república seja lugar de desenvolvimento da formação humanística do estudante, na qual o dever e responsabilidade com o patrimônio seja incentivado pelo espírito de solidariedade e cidadania. Visa-se então o cumprimento e a compreensão dos deveres para que ocorra um vínculo comunitário e, conforme o Artigo $5^{\circ}$, cada república estudantil deverá ter seu próprio regimento interno (Resolução Cuni, UFOP, 2010). Nos capítulos seguintes, dispõem-se as atribuições das residências estudantis segundo a ética de responsabilidade dos moradores e as sanções nas esferas administrativa, penal e civil advindas pelos atos praticados no uso interno da casa. 


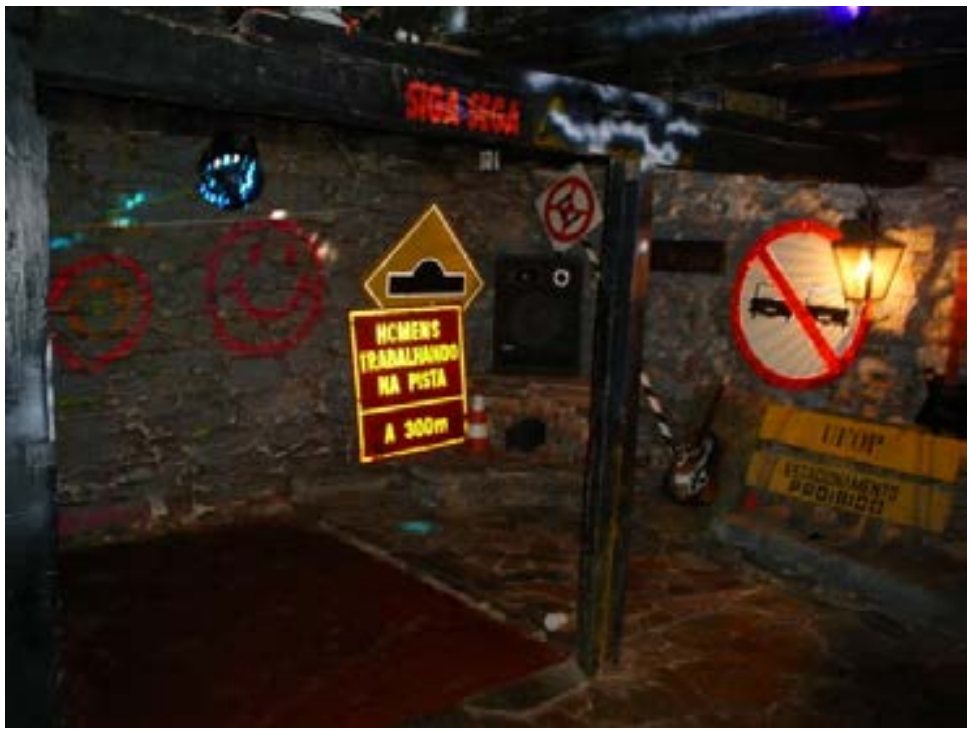

Figura 3 - Usos das casas. Fonte: Autoral, 2009.

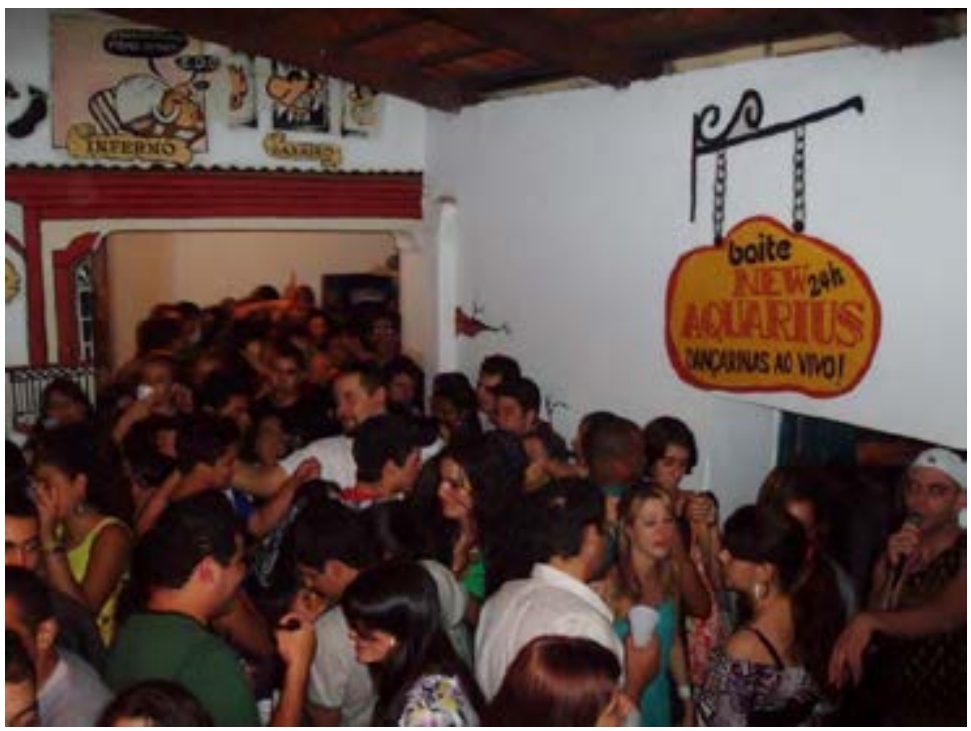

Figura 4 - Usos das casas. Fonte: República Aquarius, 2006. 


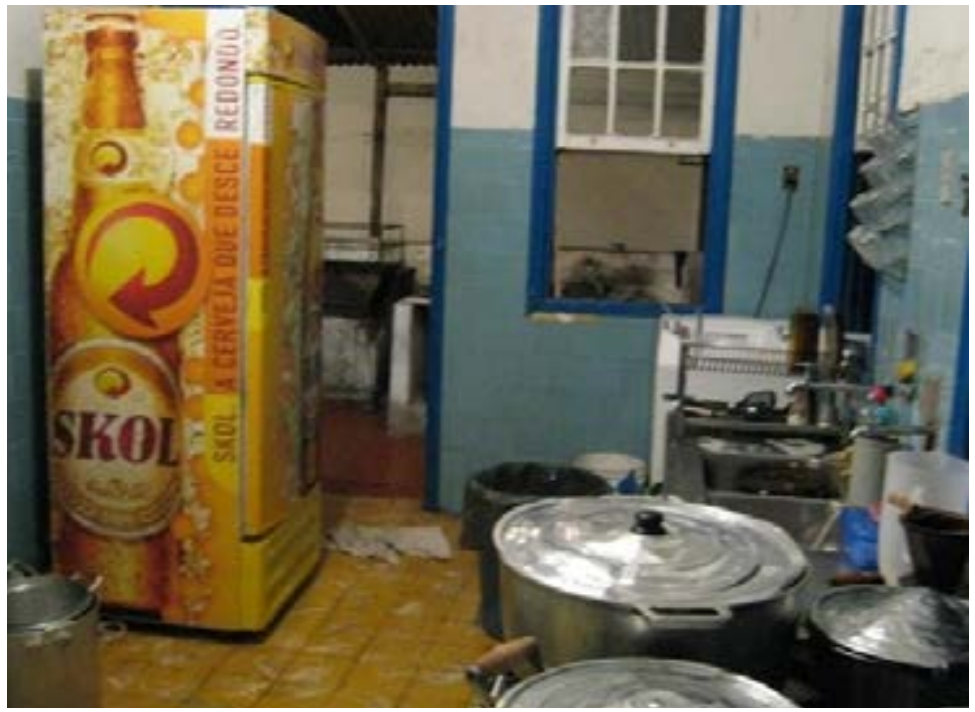

Figura 5 - Usos das casas. Fonte: Autoral, 2009.

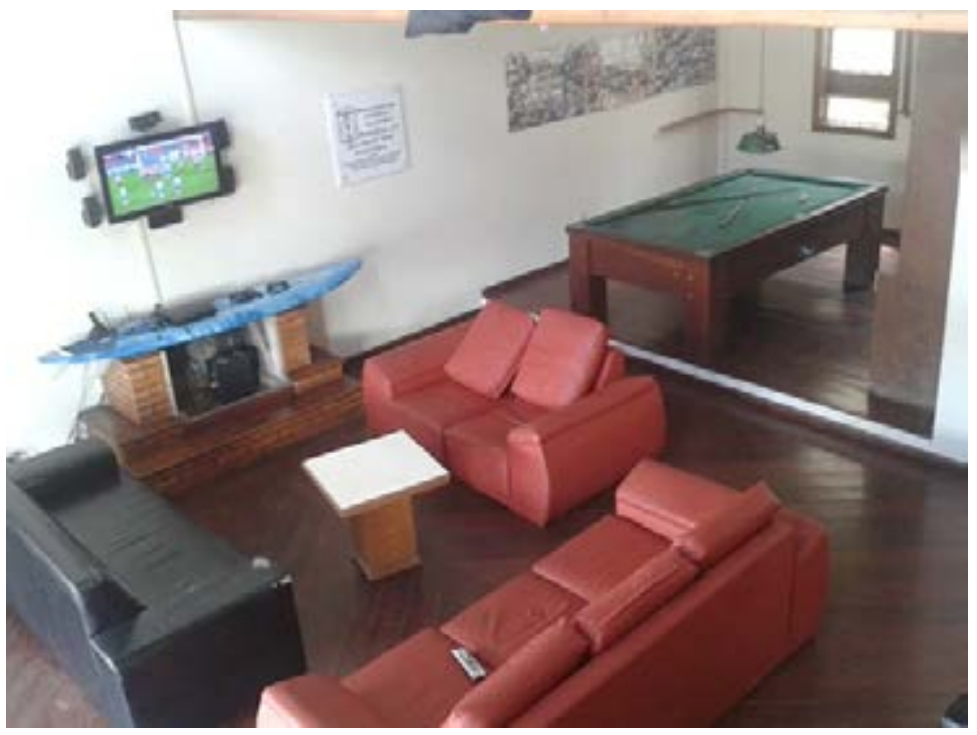

Figura 6 - Usos das casas. Fonte: República 171, 2018. 


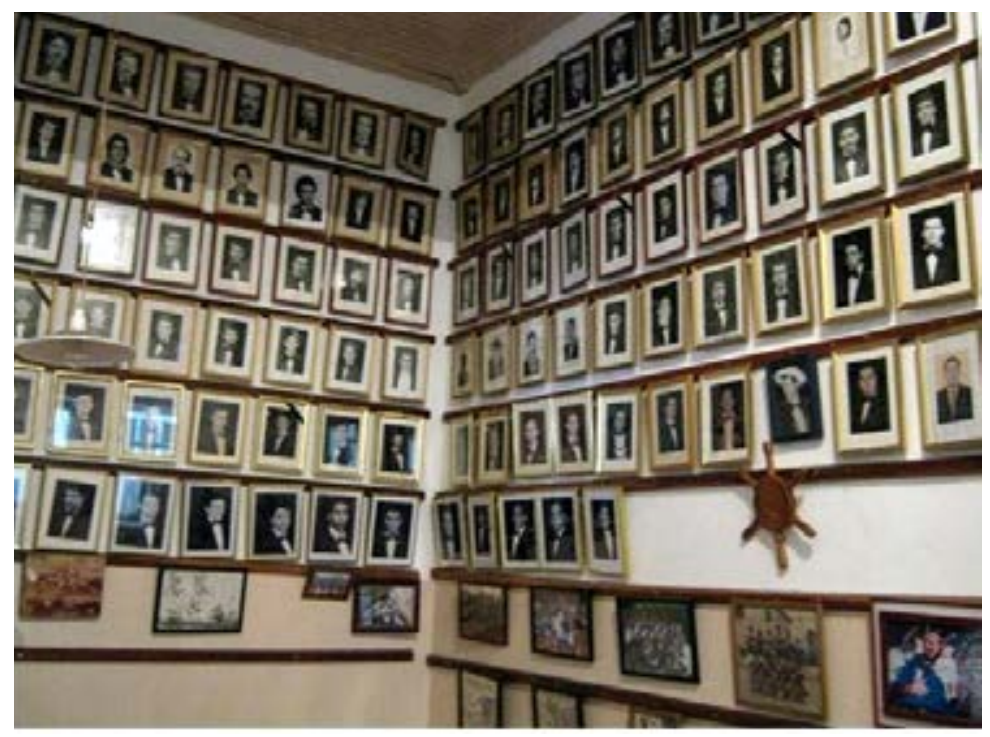

Figura 7 - Memórias estudantis. Fonte: Autoral, 2010.

Por serem tombados, os imóveis só podem sofrer alguma intervenção na estrutura física quando submetidos ao IPHAN para autorização, conforme dispõem os artigos 17 e 18 do Decreto-Lei n ${ }^{\circ}$ 25 de 30 de novembro de 1937. Caso não ocorra a autorização ou que se constate alguma intervenção feita sem aviso prévio, aos proprietários incorrerão multas. Esta regra não remete somente aos estudantes moradores de repúblicas no centro histórico da cidade, mas a qualquer morador que tenha sua residência situada na área tombada (Iphan, 2010). Mas há diversas intervenções feitas pelos estudantes no interior das antigas casas quando constroem salas de estudos com computadores, bibliotecas e equipamentos de audiovisual, o que gera benefícios com a manutenção do local (sala ou quarto) e com a renovação da fiação elétrica das casas antigas, sendo assegurado tal direito conforme as necessidades diárias e a adoção de procedimentos de autogestão de cada residência.

É permitido também o uso e a apropriação dos espaços para alojamento de terceiros, para visitas de familiares, colegas de curso e eventuais convidados. Somente é vedado o alojamento para fins 
lucrativos como o aluguel de quartos para visitantes. Entre os deveres, a administração e a conservação do patrimônio estabelece-se em primeiro plano. Entre outros deveres, deve-se manter respeito mútuo entre os pares envolvidos no uso das casas, e o cumprimento das normas de conservação do imóvel.

De qualquer modo, os moradores diversificam o cotidiano da casa entre estudos e lazer devido ao alto custo do consumo cultural ouro-pretano. Muitos serviços circunscritos no perímetro do conjunto histórico são principalmente voltados para um público turístico de alta renda e tornaram-se caros para os estudantes e moradores em geral. A falta de opções noturnas e para fins de semana na cidade indica ser um dos fatores principais para a ausência de muitos espaços de lazer e entretenimento, mesmo que seja considerável o grande fluxo de jovens durante todo o ano. Logo, as repúblicas possuem equipamentos que as tornam lugar de sociabilidades e entretenimento diversos.

No geral as áreas são apropriadas e transformadas em espaços de sociabilidades cotidianas (festas, reuniões, práticas esportivas, filmes etc.). Evidentemente, na organização de cada república muitos espaços são salas para estudos, informática e necessidades diversas da vida universitária. Os moradores dividem os usos conforme o tamanho das casas, a quantidade de quartos e o número de pessoas. Nas repúblicas federais, os grandes quartos e halls dos antigos sobrados, as cozinhas equipadas com fogões industriais e grandes mesas de jantar, tornam-se os mais variados espaços que atendem ao cotidiano dos alunos, tanto para a sociabilidade quanto para a rotina de estudos e afazeres. Já nas particulares, esta estrutura é menos provável, pois depende do imóvel alugado e das condições socioeconômicas dos alunos. Algumas repúblicas federais possuem boates e equipamento de som instalados nos porões, quartos ou salas, freezers oficiais de marcas de cervejas, áreas de festas, mesas de jogos, churrasqueiras etc.

Algumas repúblicas possuem essas características e tornamse, então, lugar de lazer, estudos, sociabilidade e turismo. Observamos em pesquisa direta a apropriação do espaço das casas para usos que não sejam os modos de habitar, como na Rua Paraná, onde há muitas repúblicas instaladas em casas antigas, a exemplo das 
Repúblicas Aquarius, Xeque-Mate, Nau Sem Rumo, Sinagoga, entre outras. Mas em alguns casos estes equipamentos são instalados sem anuência, o que gera diversos conflitos entre as repúblicas e o IPHAN. Além disso, devido ao alto volume das músicas das boates e a constante prática das festas, chamadas de "Rock" ${ }^{14}$, há conflitos com moradores vizinhos.

Viver em repúblicas não se traduz em uma escolha aleatória. Neste caso, sair de casa e do município de origem para ingressar nas universidades de outras cidades torna-se um desafio pessoal e coletivo para os jovens estudantes. A coabitação e o convívio com pessoas desconhecidas, desiguais e diferentes, faz da república um lugar em que compartilhar a identidade e os estilos de vida torna-se um aspecto necessário para que um morador permaneça na casa até o fim do curso. Além disso, compartilham-se as experiências comuns não somente no espaço da casa, mas na própria inserção dos estudantes na cidade.

Os jovens possuem então um quarto próprio, mas que agrega diferentes significados do quarto na esfera familiar. Ter um quarto próprio não significa exatamente que, desde o primeiro dia, cada estudante terá seu lugar próprio. A cultura do quarto próprio enunciou-se desde as gerações dos anos 60 em diante, quando o quarto foi reivindicado primeiramente pelas jovens como espaços de sociabilidades e de exercício da intimidade femininas, pois é comum na cultura juvenil feminina não haver disjunções na intimidade do corpo ao trocar de roupa ou ir ao banheiro, além da troca de artefatos e signos culturais (os diários, os cosméticos, roupas etc.). Como é sabido, as mulheres (mãe, filhas, amigas) costumam estar mais à vontade e próximas entre elas. Já os homens reivindicaram os equipamentos públicos como praças e quadras de esportes, pubs, cafés etc, ganhando as ruas mais cedo. Contudo, os jovens em geral apropriaram-se dos quartos para formar associações e desenvolverem atividades práticas como ouvir e tocar músicas, ver filmes etc.

$14 \mathrm{O}$ rock em Ouro Preto é uma forma de enunciação de práticas cotidianas e festivas dos republicanos e estudantes em geral, que inicialmente derivou da prática subversiva de contrapor normas do próprio Rock n' Roll. Aqui é também uma categoria espacializante do cotidiano estudantil e, em certa medida, conforme a própria designação confronta "a calmaria da Cidade Monumento". É uma maneira de apropriar-se dos espaços cotidianos de uma cidade demarcada por normas que restringem usos diversos na cidade. 
A questão que se levanta é outra. Enquanto geralmente os jovens-adolescentes buscam maior liberdade, fogem da vigilância dos pais ou vivem nos seus próprios quartos, transformando-os muitas vezes em um lugar íntimo, fechado; também abstêm-se de algumas responsabilidades da casa e procuram construir suas identidades ao lado dos amigos percorrendo os lugares distantes do bairro. Os jovens repúblicos de Ouro Preto, embora estejam distantes da família, deparam-se com a responsabilidade de cuidar da casa e com o aprendizado de tarefas domésticas, mesmo que tenham uma "cumadre" para fazer o almoço e a limpeza diária.

Não é possível afirmar que um republicano tenha a casa inteira só para ele. A república é também lugar de convivência e divisão de bens e espaços. As repúblicas diferem-se dos pensionatos e de muitos tipos de moradia em que as pessoas dividem um apartamento, mas não compartilham bens, tais como comidas e produtos diários. O "sistema das repúblicas" compreende por um lado, regras, princípios e tradições que orientam os moradores sobre o que pode ou não ser feito na república: são responsabilidades para com a casa (saber trocar uma lâmpada, consertar uma torneira etc.) e com os outros (o bem-estar de cada um). Além da divisão de tarefas, há a divisão das hierarquias da casa que começa pelo membro mais velho (o Decano) até os recém-chegados (semi-bixo e bixo), preza-se o respeito mútuo e confiança entre os membros. Este "sistema" é válido para qualquer república masculina, mista ou feminina. Neste caso, as ações e comportamentos individuais são de alguma forma observados, críveis de um controle interno. Por outro, os moradores dispõem de liberdade individual, do respeito com o modo de vida e a cultura de cada morador, mas sobretudo, da sociabilidade cotidiana.

Estas responsabilidades são informadas através dos relatos de ex-moradores de repúblicas, de quem visitou ou morou por um curto período, como também circulam diversas informações na internet. Em sua grande maioria, os enunciados convergem com a ideia de que "morar em república é um aprendizado para toda a vida"; "a república é uma Escola de vida". Ingressar na Universidade tornase então um dos mais importantes momentos de transição da vida 
de muitos jovens, pois é no ensino superior que encontramos maior liberdade de escolha para um futuro pessoal e profissional, mesmo ao lado de grandes inquietações, ainda mais se vamos estudar e morar longe de casa com outras pessoas, até então desconhecidas, por pelo menos 4 ou 5 anos. Este período demarca fortemente a pós-adolescência. É quando os jovens experimentam novas identidades, transitam para outras visões de mundo (políticas e socioculturais) decorrentes não só de novos contatos, mas da própria vinculação ao mundo acadêmico.

Observamos, tanto em forma teórica quanto através da nossa imersão em campo, as práticas culturais estudantis nos diversos espaços da cidade. Ocorrem através dos usos e apropriações dos antigos sobrados como lugar de moradia e lazer, principalmente no centro histórico, onde há maior interação com o fluxo de turistas da cidade, visto que estes se hospedam também nas repúblicas.

As repúblicas tornam-se então lugares fragmentários no contexto relacional ouro-pretano, pois nelas há práticas cotidianas diferenciadas de outros lugares da cidade, compartilhadas como conjuntos de ações próprias. Mas também são híbridas quantos aos diferentes usos que demarcam o lugar. São conjuntos de ações que sugerem não só uma tradição, mas convergências de sentidos quanto ao que se pratica nestes espaços. Segundo a proposta de Leite (2007) acerca da existência dos lugares, podemos entender que as sociabilidades entre as repúblicas imprimem ações simbólicas e conteúdos culturais que são compartilhados reflexivamente entre os moradores. Suas fronteiras são flexíveis à medida que permitem interações públicas entre as diferentes identidades e expressam dissensões ou convergência de sentidos e estilos de vida.

\section{CONSIDERAÇÕES FINAIS}

Responder porque importa estudar práticas cotidianas - socioculturais e espaciais - é um empreendimento que pretende mostrar como se manifesta a pluralidade do cotidiano. Especificamente em Ouro Preto, a sociabilidade é marcada por incidências identitá- 
rias bastante dinâmicas e de significação para o entendimento da sociabilidade juvenil contemporânea. Afirmamos que as práticas protagonizadas pelos estudantes têm forte inscrição sociossimbólica ao passo que estende formas de usos do patrimônio e dos espaços urbanos da cidade histórica.

A "Cidade Histórica" é antes apresentada para o turismo como aporte de reconhecimento dos bens culturais materiais e imateriais ouro-pretanos e nacionais, e isto não caracteriza, como ocorre em Coimbra, a identificação entre a imagem patrimonial e a imagem de cidade universitária. Assim, o que poderia ser articulação entre a " $\mathrm{Ci}$ dade Histórica" e a "Cidade Universitária" como patrimônios, decorre antes sua disjunção, por isso, talvez, as próprias repúblicas e os modos de vida dos estudantes não sejam consideradas patrimônio cultural. Mesmo que não sejam tombadas como parte do acervo cultural, as repúblicas são propriedades públicas da Escola de Minas e, portanto, seus usos são definidos por estatutos elaborados pela UFOP.

$\mathrm{Na}$ literatura sobre a cidade, é pouco mencionada a importância da cultura universitária na construção da imagem e do patrimônio material e imaterial. Podemos atribuir às repúblicas instaladas no Centro não só o papel de conservar o casario edificado, mas também o papel de bem cultural a ser preservado em face de sua inscrição junto à identidade patrimonial da cidade. É preciso notar que a presença dos estudantes imprimiu novos hábitos à vida urbana ouro-pretana e, neste entretempo, muitas mudanças fizeram rearranjar tradições, usos das casas nas áreas centrais e a sociabilidade cotidiana da antiga Vila Rica.

No caso das repúblicas federais, embora existam normas que regulem os usos e responsabilizem os moradores por qualquer ato considerado ilegal ao bem público, muitas têm a característica de $l u$ gar, visto que, para além de ser uma casa de estudantes restrita para tal uso, ela é uma demarcação espacial permeada por ações simbólicas e interações sociais públicas. Como observa Certeau (1994), o ato de nomear um espaço - cada república tem seu "nome" - é central para o processo de criação dos lugares. Os usos das casas ocorrem dentro de estruturas regulatórias existentes (impostas), mas 
conseguem flexibilidade diante das regras disciplinares criadas pelas leis de proteção ao patrimônio público.

Poderíamos, provavelmente, dizer que em Ouro Preto as repúblicas se tornaram o maior patrimônio da Universidade e fazem parte do patrimônio cultural juvenil da cidade. São também, como as ruas, espaços juvenis de busca da liberdade, de práticas autônomas e da vida boêmia sem o controle familiar. Neste sentido, os usos que os jovens fazem dos espaços e do tempo constituem um domínio de afirmação das identidades, das linguagens e estilos de vida, tanto em nível simbólico e discursivo quanto em nível prático.

Portanto, a inscrição sociossimbólica da Universidade e das repúblicas na imagem e paisagem urbana ouro-pretana pode ser narrada enquanto parte de um acervo cultural bastante ramificado. A "cidade das repúblicas" mostra-se como um espaço cultural cambiante, elaborado e reelaborado constantemente por um público flutuante de jovens estudantes que inscrevem na vida urbana cotidiana de Ouro Preto imagens, signos e ruídos que fazem desta cidade de estudantes um espaço público de práticas sociais, sociabilidades e de identidades culturais dissonantes. 


\section{REFERÊNCIAS}

CARVAlHO, J. M. A Escola de Minas de Ouro Preto: o peso da glória. São Paulo: Nacional; Rio de Janeiro: Financiadora de Estudos e Projetos, 1978.

CÂMARA MUNICIPAL DE OURO PRETO. Acompanhe a polêmica sobre as repúblicas de Ouro Preto, 2006. Disponível em: http:// www.cmop.mg.gov.br/index.php?option $=$ com_content\&view $=$ arti cle\&id=279:acompanhe-a-polemica-sobre-as-republicas-de-ouropreto\&catid=62:outros. Acesso em: 23 jun. 2010.

CERTEAU, M. A invenção do cotidiano: artes de fazer. Petrópolis, RJ: Vozes, 1994. . A Cultura no Plural. São Paulo: Papirus, 1995.

CIFELLI, G. Turismo, patrimônio e novas territorialidades em Ouro Preto - MG. 2005. Dissertação (Mestrado em Geografia), Universidade Estadual de Campinas, Instituto de Geociências, Campinas.

COSTA, A. F. Identidades culturais urbanas em época de Globalização. Rev. bras. Ci. Soc., v. 17, nº 48, pp. 15-30, 2002.

CRIVELlaRI, H. M. T. A Trama e o Drama do Engenheiro: mudança de paradigma produtivo e relações educativas em Minas Gerais. 1998. Tese (Doutorado em Educação), Universidade Estadual de Campinas, Faculdade de Educação, Campinas.

DEQUECH, D. Isto Dantes em Ouro Preto: Crônicas. Belo Horizonte: Minas Gráfica, 1984.

FORTUNA, C. Destradicionalização e imagem da cidade: o caso de Évora. In: FORTUNA, C. (Org.). Cidade, cultura e globalização: ensaios de sociologia. Oeiras: Celta, 1997.

- Culturas urbanas e espaços públicos: sobre as cidades e a emergência de um novo paradigma sociológico. Rev. Cr. Ci. Soc., $n^{\circ} .63$, pp.123-148, 2002.

FRIAS, A. Praxe académica e culturas universitárias em Coimbra: Lógicas da tradição e dinámicas identitárias. Rev. Cr. Ci. Soc., nº. 66, pp. 81-116, 2003.

GOMES, C. Imagens e narrativas da Coimbra turística: Entre a cidade real e a cidade (re)imaginada. Rev. Cr. Ci. Soc., no. 83. pp. 55-78, 2008.

GONÇALVES, J. R. S. A retórica da perda: os discursos do patrimônio cultural no Brasil. Rio de Janeiro: Editora da UFRJ; MinC; IPHAN, 1996.

. O mal-estar no patrimônio: identidade, tempo e destruição. Estudos Históricos. Rio de Janeiro, vol. 28, nº 55, pp. 211-228, 2015. 
INSTITUTO DO PATRIMÔNIO HISTÓRICOE ARTÍSTICO NACIONAL. Portaria $n^{\circ} 312$, de 20 de Outubro de 2010. Disponível em: http:// portal.iphan.gov.br/portal/baixaFcdAnexo.do?id=2107. Acesso em: 10 dez. 2010.

LEITE, R. P. Contra-usos da cidade: Lugares e espaço público na experiência urbana contemporânea. $2^{\mathrm{a}}$ ed. Campinas: UNICAMP; Aracaju: EDUFS, 2007.

. Cities and Gentrification in Contemporary Brazil. Current Urban Studies. vol. 3, nº. 3, pp. 175-186, 2015.

LESSA, M. A. Ouro Preto do meu tempo. 2. ed. São Paulo: IBRASA, 1981.

MACHADO, O. L. Casas de estudantes e Educação Superior no Brasil: aspectos sociais e históricos, In: ZAIDAN, M.; MACHADO, O. L. (Orgs.), Movimento Estudantil Brasileiro e a Educação Superior. Recife: Universitária UFPE, 2007.

MACHADO, O. L. As repúblicas estudantis da Universidade Federal de Ouro Preto, Brasil, Rev. Cr. Ci. Soc., no. 66, pp. 197-199, 2003.

MALTA, E. Imagens e identidade cultural de Ouro Preto: repúblicas estudantis e patrimônio. In: TAMASO, I. M; FILHO, M. F. Antropologia e patrimônio cultural: trajetórias e conceitos. Brasília: Associação Brasileira de Antropologia, vol.1, 2012. pp. 185-218.

MARGULIS, M; URRESTI, M. La juventud es más que una palabra. In: MARGULIS, M. (Org.). La juventud es más que una palabra: Ensayos sobre cultura y juventud. Buenos Aires: Biblos, 2000. pp. 13-30.

MARTÍN-BARBERO, J. Dos meios às mediações: comunicação, cultura e hegemonia. Rio de Janeiro: UFRJ, 1997.

MENICONI, R. O. M. A construção de uma cidade monumento: o caso de Ouro Preto. 1999. Dissertação (Mestrado em Arquitetura e Urbanismo), Universidade Federal de Minas Gerais, Escola de Arquitetura e Urbanismo, Belo Horizonte.

MOTTA, L. A SPHAN em Ouro Preto: uma história de conceitos e critérios. Revista do Patrimônio Histórico e Artístico Nacional, $\mathrm{n}^{\circ}$. 22, Rio de Janeiro: IPHAN, 1987.

NATAL, C. M. Ouro Preto: a construção de uma cidade histórica (18911933). 2007. Dissertação (Mestrado em História), Universidade Estadual de Campinas, Instituto de Filosofia e Ciências Humanas, Campinas.

NILAN, P.; FEIXA, C. Introduction: Youth hybridity and plural worlds. In: ______. (Eds.). 2006: Global Youth? Hybrid identities, plural worlds. New York: Routledge, 2006.

OLIVEIRA, L. L. Cultura é patrimônio: um guia. Rio de Janeiro: Editora FGV, 2008. 
PAIS, J. M. Culturas Juvenis. 2. ed. Lisboa: INCM, 2003. . Sociologia da vida quotidiana: teoria, métodos e estudos de caso. $3^{\mathrm{a}}$ ed., Lisboa: Impressa de Ciências Sociais, 2007.

QUEIROZ, M. A. N. F. Ouro Preto e Mariana. In: ARANTES, A. A. (Org.). Produzindo o passado: estratégias de construção do patrimônio cultural. São Paulo: Brasiliense, CONDEPHAAT, 1984.

RUBINO, S. Nem findas nem lidas: cidades e gestão da memória. In: LEITE, R. P. (Org.). Cultura e vida urbana: Ensaios sobre a cidade. São Cristóvão/SE: EDUFS, 2008.

SENNETT, R. O Declínio do Homem Público. São Paulo: Companhia das Letras, 1998.

SIMMEL, G. Questões fundamentais da Sociologia: indivíduo e sociedade. Rio de Janeiro: Jorge Zahar, 2006.

STECANELA, N. O cotidiano como fonte de pesquisa nas Ciências Sociais. Conjectura: Filosofia e Educação. v. 14, no.1, pp. 63-75, 2009.

SMITH, D. P. "Studentification": the gentrification factory? In: ATKINSON, R.; BRIDGE, G. Gentrification in a global context: the new urban colonialism. Routledge UK: Housing and Society Series, 2005. pp. 72-89.

TAMASO, I. A Cruz do Anhanguera: representações, experiências, memórias, patrimônio. In: FRÚGOLI Jr., H.; ANDRADE, L. T.; PEIXOTO, F. A. (Orgs.). As cidades e seus agentes: práticas e representações. Belo Horizonte: Editora PUC Minas; São Paulo: Edusp, 2006. pp. 245-273.

UNESCO. Committee Decisions ( $37^{\mathrm{a}}$ Convention): Cultural Properties - University of Coimbra - Alta and Sofia, Portugal. WHC-13/37. COM/8B. Phnom Penh, Cambodia, 2013. Disponível em: http:// whc.unesco.org/archive/2013/whc13-37com-8B-en.pdf. Acesso em: 25 set. 2016.

UNIVERSIDADE FEDERAL DE OURO PRETO (UFOP). Resolução CUNI, $n^{\circ}$. 1.150, In: Estatuto das Repúblicas Federais de Ouro Preto, 2010.

WIRTH, L. O urbanismo como modo de vida. In: FORTUNA, C. (Org.). Cidade, cultura e globalização: ensaios de sociologia. Oeiras: Celta, 1997. pp. 45-65. 